\title{
Engineering and characterization of human $\beta$-defensin- 3 and its analogues and microcin J25 peptides against Mannheimia haemolytica and bovine neutrophils
}

\author{
Harpreet Dhingra ${ }^{1}$, Kamaljit Kaur ${ }^{2}$ and Baljit Singh ${ }^{1 *}$ (1)
}

\begin{abstract}
Mannheimia haemolytica-induced bovine respiratory disease causes loss of millions of dollars to Canadian cattle industry. Current antimicrobials are proving to be ineffective and leave residues in meat. Antimicrobial peptides (AMPs) may be effective against M. haemolytica while minimizing the risk of drug residues. Cationic AMPs can kill bacteria through interactions with the anionic bacterial membrane. Human $\beta$-Defensin 3 (HBD3) and microcin J25 (MccJ25) are AMPs with potent activity against many Gram-negative bacteria. We tested the microbicidal activity of wild-type HBD3, three HBD3 peptide analogues (28 amino acid, 20AA, and 10AA) derived from the sequence of natural HBD3, and MccJ25 in vitro against M. haemolytica. Three C-terminal analogues of HBD3 with all cysteines replaced with valines were manually synthesized using solid phase peptide synthesis. Since AMPs can act as chemoattractant we tested the chemotactic effect of HBD3, 28AA, 20AA, and 10AA peptides on bovine neutrophils in Boyden chamber. Minimum bactericidal concentration $(M B C)$ assay showed that $M$. haemolytica was intermediately sensitive to HBD3, 28AA and 20AA analogues with an $\mathrm{MBC}$ of $50 \mu \mathrm{g} / \mathrm{mL}$. The $10 A \mathrm{~A}$ analogue had $\mathrm{MBC} 6.3 \mu \mathrm{g} / \mathrm{mL}$ which is likely a result of lower final inoculum size. MccJ25 didn't have significant bactericidal effect below an $\mathrm{MBC}<100 \mu \mathrm{g} / \mathrm{mL}$. Bovine neutrophils showed chemotaxis towards HBD3 and 20AA peptides $(P<0.05)$ but not towards 28AA analogue. Co-incubation of neutrophils with any of the peptides did not affect their chemotaxis towards N-formyl-L-methionylL-leucyl-phenylalanine (FMLP). The data show that these peptides are effective against M. haemolytica and are chemotactic for neutrophils in vitro.
\end{abstract}

Keywords: HBD3, Microcin J25, Cationic anti-microbial peptides, Solid phase peptide synthesis (SPPS), Bovine neutrophils, Chemotaxis

\section{Introduction}

Cattle industry is a major contributor to global economy and is expected to play a critical role in meeting nutritional needs of expanding middle classes in emerging economies such as China and India. For example, Canada

\footnotetext{
*Correspondence: baljit.singh@usask.ca

${ }^{1}$ Department of Veterinary Biomedical Science, Western College

of Veterinary Medicine, University of Saskatchewan, Saskatoon, SK S7N 5B4, Canada

Full list of author information is available at the end of the article
}

has nearly 83000 cattle farms and ranches and this sector contributes upwards of $\$ 20$ billion a year to Canadian economy [1]. The beef and dairy cattle industry suffer significant economic losses due to Mannheimia haemolytica-induced Bovine respiratory disease (BRD) [2]. M. haemolytica, a Gram-negative coccobacillus that causes pneumonia in cattle, resides in the nasopharynx of cattle in a commensal relationship, but stress and viral infections compromise host defenses giving $M$. haemolytica an opportunity to invade lungs and cause infection [3].

c) The Author(s) 2021. This article is licensed under a Creative Commons Attribution 4.0 International License, which permits use, sharing, adaptation, distribution and reproduction in any medium or format, as long as you give appropriate credit to the original author(s) and the source, provide a link to the Creative Commons licence, and indicate if changes were made. The images or other third party material in this article are included in the article's Creative Commons licence, unless indicated otherwise in a credit line to the material. If material is not included in the article's Creative Commons licence and your intended use is not permitted by statutory regulation or exceeds the permitted use, you will need to obtain permission directly from the copyright holder. To view a copy of this licence, visit http://creativeco mmons.org/licenses/by/4.0/. The Creative Commons Public Domain Dedication waiver (http://creativecommons.org/publicdomain/ zero/1.0/) applies to the data made available in this article, unless otherwise stated in a credit line to the data. 
A variety of vaccines and antibiotics against $M$. haemolytica are available but control and prevention are still a problem and due to which approximately $\$ 1$ billion per year are lost by the US cattle industry [2-6] with similar relative losses in other countries such as Australia and Canada [7]. There is a growing evidence of development of resistance in $M$. haemolytica against commonly used antimicrobials and a call to take quick steps to develop new and effect anti-microbials to combat this pathogen $[8,9]$. Problems such as antibiotic resistance, antibiotic residue in meat and an inadequacy of vaccines push for the search of alternative treatments.

In this context, antimicrobial peptides (AMPs) have received significant attention as alternatives to antibiotics $[10,11]$. Human $\beta$-Defensin 3 (HBD3) has been isolated from airways surface fluid from patients with psoriasis, suggesting it may play a role in fighting local infection [12]. Recent work by the Caswell laboratory has shown that treatment with naturally expressed Tracheal Antimicrobial Peptide, a defensin, neither killed M. haemolytica nor prevented the development of lung disease [13, 14]. Coupled with the fact that $M$. haemolytica, in normal condition, is prevented from entering into the lungs by the host's innate defense mechanism which includes the bovine defensins [3], it was thought that HBD3 peptide might be effective in $M$. haemolytica-induced pneumonia. Microcins are another class of AMPs which are produced by bacteria such as $E$. coli. Microcins inhibit the growth of many pathogenic Gram-negative bacteria with Minimum inhibitory concentration (MIC), in the nanomolar range [11, 15-20]. Specifically, Microcin)25 (Mcc)25) is a peptide comprised of 21 amino acids and is active against many Gram-negative bacteria such as Escherichia coli and Salmonella [21]. Mccj25 is stable in the presence of many proteolytic enzymes because of its unique lasso like structure [11]. Considering the economic impact of $M$. haemolytica infections in cattle and lack of effective anti-microbial peptides to replace antibiotics, we hypothesize that HBD3 and MccJ25 might prove as potential candidates for application in the treatment of BRD. The objective of the current study was to design, synthesize, purify and evaluate the antimicrobial activity of HBD3, its analogues, and recombinant MccJ25 against $M$. haemolytica.

\section{Materials and methods}

\section{Expression and purification of microcin $\mathbf{J 2 5}$}

Wild-type Microcin J25 (MccJ25) was used in this study as formation of the lasso ring is not possible synthetically. The peptide was expressed using MccJ25 biosynthetic gene cluster carrying plasmid pTUC202 (a gift from Rutgers University USA) in competent E. coli MC4100 cells [25]. It was grown in $2 \mathrm{~L} \mathrm{M9}$ minimal media for $18 \mathrm{~h}$ at $37^{\circ} \mathrm{C}$. The culture supernatant was obtained by centrifugation at $4000 \mathrm{~g}$ for $15 \mathrm{~min}$, and then subjected to two successive purification steps. First, it was applied on the flex column filled with XAD16 resin (Sigma-Aldrich, St. Louis, USA). Two successive elution steps were performed with $(30: 70, \mathrm{v} / \mathrm{v})$ and $(80: 20, \mathrm{v} / \mathrm{v})$ methanol/water mixtures. Mcc)25 is eluted in the (80:20, v/v) methanol/ water mixture. Mcc)25 was purified using reversed-phase (RP) HPLC (Varian Prostar 210, SpectraLab Scientific Inc. Markham, Canada). The purity of the peptides was confirmed by MALDI-TOF mass spectrometry.

\section{Synthesis and purification of HBD3 analogues}

HBD3 fragments were synthesized manually on 2-chlorotrityl chloride resin $(0.2 \mathrm{mmol}, 1 \mathrm{mmol} / \mathrm{g})$ following the standard Fmoc solid phase peptide synthesis (SPPS) [22]. The first amino acid was coupled using DIPEA for $5 \mathrm{~h}$. Further amino acids were coupled at twofold excess using $\mathrm{HCTU} / \mathrm{HOBT} / \mathrm{NMM}$ as activating mixture in DMF. Amino acid coupling was performed for $3 \mathrm{~h}$ at room temperature to ensure the completeness of the reaction, followed by Fmoc group deprotection using piperidine in DMF. These two reactions were repeated until assembly of the peptide was complete. A Kaiser test was performed after coupling of each amino acid. After completion of the synthesis, peptides were cleaved from the resin and all protecting groups were removed using cleavage mixture at room temperature. Cleaved peptide was concentrated by rotary evaporation. Cold ether was added to precipitate the peptide and crude peptide was isolated after centrifugation. Crude peptides were dissolved in water and purified using RP-HPLC (Varian Prostar 201). The purity of the peptides was confirmed by RP-HPLC and MALDI-TOF mass spectrometry.

\section{Antimicrobial activity testing of peptides}

Wild-type HBD3, its analogues, and Mcc)25 were tested against $M$. haemolytica- $A 1$ using optical density method and colony count assay. Briefly, an aliquot $(5 \mu \mathrm{L})$ from bacteria suspension stored at $-80{ }^{\circ} \mathrm{C}$ was put in $5 \mathrm{~mL}$ BHI broth at $37^{\circ} \mathrm{C}$ for $18 \mathrm{~h}$. An aliquot $(10 \mu \mathrm{L})$ from this overnight culture was added to fresh BHI broth and incubated at $37^{\circ} \mathrm{C}$ for a further $5 \mathrm{~h}$ to obtain mid-log phase bacteria. The culture was then centrifuged for $10 \mathrm{~min}$ at $800 \mathrm{~g}$ at $4{ }^{\circ} \mathrm{C}$. The supernatant was discarded and the bacterial pellet was resuspended in cold, sterile sodium phosphate buffer (SPB) and washed again at $800 \mathrm{~g}$ for $10 \mathrm{~min}$ at $4{ }^{\circ} \mathrm{C}$. The pellet was resuspended in $5 \mathrm{~mL} \mathrm{SPB}$. To calculate the number of $\mathrm{CFU} / \mathrm{mL}$ in the $5 \mathrm{~h}$ culture, six successive tenfold dilutions were made. From the last dilution $100 \mu \mathrm{L}$ was plated in duplicate on petri dishes containing BHI agar and incubated for $24 \mathrm{~h}$. After $24 \mathrm{~h}$ the colonies were counted in the two petri dishes and 
then averaged. Total number of colonies was the average number of colonies multiplied by the dilution factor.

All assays were carried out in sterile 96-well polypropylene flat-bottomed plates using a broth microdilution method. Two-fold serial dilutions of peptide were made in $\mathrm{SPB}$, and $50 \mu \mathrm{L}$ of each concentration of peptide was added to the wells of the assay plate. Fifty $\mu \mathrm{L}(25000$ cells) of the bacterial suspension adjusted to $5 \times 10^{5} \mathrm{cfu} /$ $\mathrm{mL}$ in incubation media was prepared by adding $200 \mu \mathrm{L}$ of BHI broth in $6.8 \mathrm{~mL} \mathrm{SPB}$ and added to each well. Positive control wells contained $50 \mu \mathrm{L}$ of the bacteria with $50 \mu \mathrm{L}$ of $64 \mu \mathrm{g} / \mathrm{mL}$ ampicillin and negative control wells contained $50 \mu \mathrm{L}$ of SPB and $50 \mu \mathrm{L}$ bacterial suspension. Sterility control well contained $100 \mu \mathrm{L}$ BHI broth to test and ensure that broth was not contaminated.

The plates were sealed with aluminum foil and were incubated at $37^{\circ} \mathrm{C}$ for $2 \mathrm{~h}$ then $50 \mu \mathrm{L}$ of the contents of the well were pipetted on BHI agar plates and incubated for $24 \mathrm{~h}$. The bactericidal activity was expressed as the $\mathrm{MBC}$ which is the concentration at which $99.9 \%$ of the colonies are killed and the Lethal dose $50\left(\mathrm{LD}_{50}\right)$ at which $50 \%$ or more bacteria are killed [23-25]. All experiments were run in triplicates.

\section{Polymorphonuclear cell isolation and chemotaxis assay Polymorphonuclear cell isolation}

Neutrophils were isolated from cattle using established methods and approved by the University of Saskatchewan's Committee on Animal Care [26]. For each individual animal, blood was pooled into $50 \mathrm{~mL}$ tubes and diluted with an equal volume of PBS then $12.5 \mathrm{~mL}$ of the diluted blood was layered over $10 \mathrm{~mL}$ of Ficoll Paque PLUS (Sigma-Aldrich, St. Louis, USA) while taking care to preserve the interface between the two liquids. Following centrifugation at $400 \mathrm{~g}$ for $30 \mathrm{~min}$ at $20{ }^{\circ} \mathrm{C}$ with the brake turned off, the lymphocyte layer was discarded along with Ficoll and plasma. The pellet was washed in $20 \mathrm{~mL}$ PBS with centrifugation at $500 \mathrm{~g}$ with low brake for $10 \mathrm{~min}$. The supernatant was discarded and the pellet was suspended in equal volume of sterile water and gently mixed for $20 \mathrm{~s}$ followed by addition of equal volume of $1.8 \% \mathrm{NaCl}$ to restore tonicity. The mixture was centrifuged at $500 \mathrm{~g}$ for $10 \mathrm{~min}$ and followed by another washing and centrifugation at $4{ }^{\circ} \mathrm{C}$. The resulting neutrophil pellet was resuspended in PBS. Bovine neutrophils, collected in the above manner had more than $92 \%$ purity, and their viability was greater than $95 \%$ based on Trypan blue exclusion assay. Therefore, we use the term neutrophils in the manuscript.

\section{Chemotaxis assay}

We used fMLP (114 nm) as the chemoattractant. Approximately $25 \mu \mathrm{L}$ of peptides $(50 \mu \mathrm{g} / \mathrm{mL})$ was put into lower compartment wells of a 48-well Boyden Chamber. After the fMLP loading, the polycarbonate membrane filter (pore size $5 \mu \mathrm{M}$ ), with the shiny side up, was placed over the lower chamber. Next, silicone gasket was placed on the membrane, then the upper chamber was put on top of the gasket and the lug nuts firmly secured. Cell suspension $\left(1 \times 10^{6}\right.$ cells) was then placed over control wells and N/P wells (neutrophil at top and peptide in the bottom wells). The whole assembly was then incubated at $37{ }^{\circ} \mathrm{C}$ in humidified air with $5 \% \mathrm{CO}_{2}$ for $20 \mathrm{~min}$. After the incubation, the Boyden chamber was disassembled and the membrane carefully held with the bulldog clamp and the cells on the upper shiny surface scraped with the wiper blade. Next, the filter membrane was stained with the Diff-Quick and mounted on glass slide with the bottom side up. The cells within the filter pores were then counted in five random fields under light microscope at $40 \times$. The results are presented as the number of migrated neutrophils per microscopic field.

\section{Migration inhibition assay}

Since peptides can be immunomodulatory, migration inhibition was carried out to determine if the peptides inhibit neutrophil migration. This assay was performed in the same manner as the chemotaxis assay with the only difference being that peptide and neutrophils were incubated together on the top of the filter; $25 \mu \mathrm{L}$ of $100 \mu \mathrm{g} /$ $\mathrm{mL}$ peptide and $25 \mu \mathrm{L}\left(2 \times 10^{6}\right.$ cells $)$ of neutrophils were put together. In the lower wells $25 \mu \mathrm{L}$ of $114 \mathrm{nM}$ fMLP (chemoattractant) was placed followed by the staining and counting of the cells as described above.

\section{Statistical analysis}

Data from susceptibility testing assay was analyzed using the non-parametric statistics (using ranked data), because the data were variable among groups most likely due to small sample size. The comparisons were done using contrasts (1 compared to 2, 2 compared to 3, and so on), given that we expected a decrease in colony count with increasing concentrations. Groups were considered statistically significant if the $P$-value was less than 0.05 . A One-way ANOVA followed by Dunnets Multiple Comparisons test was performed on data obtained from the chemotaxis and migration inhibition assay. Significance was recorded when $P<0.05$. Computer software GraphPad Prism 6 and SPSS (GraphPad Software, San Diego, USA) for migration and susceptibly assays, respectively, were used.

\section{Results}

Peptide design and synthesis

Five peptides, HBD3, 28AA HBD3, 20AA HBD3, 10AA HBD3, and Microcin J25 (MccJ25) were evaluated in this 
study. Because wild type HBD3 is commercially available, we purchased it at 95\% purity (AnaSpec Inc.). The amino acid sequences of the HBD3 and its analogues and MccJ25 studied are shown in Figure 1.

Approximately $3 \mathrm{mg}$ Wild-type Mcc)25 was obtained by over expression protocol already established by Soudy et al. [27]. After purification by flex column the crude Mcc)25 was finally purified with the C-18 RP-HPLC, at a flow rate of $2 \mathrm{~mL} / \mathrm{min} 55-80 \%$ methanol/water mixture in $55 \mathrm{~min}$. Various fractions at different time points were obtained. Fraction containing the desired mass for MccJ25 eluted at $20 \mathrm{~min}$ on the RP-HPLC column (Additional File 1). The calculated mass for MccJ25 was $2107 \mathrm{MW}$ and the mass was determined to be $[\mathrm{M}+\mathrm{H}]^{+}$ 2107.7 (Additional File 1). The elute from desired peak was collected, pooled and lyophilized. The yield or the concentration of MccJ25 was measured using UV-Vis spectrophotometer at $278 \mathrm{~nm}$.

\section{SPPS synthesis of HBD3 analogues}

Three C-terminal HBD3 analogues were designed as short fragments of wtHBD3 with different amino acid chain lengths (Figure 1). In each analogue, cysteine was replaced with valine to remove di-sulfide linkages and render the fragment linear and more stable. Standard SPPS with Fmoc chemistry was used for the synthesis of the three analogues. Manual SPPS was carried out in a reaction vessel starting with the shorter 10AA analogue. Amino acid chain was built on 2-chlorotrityl resin in the reaction vessel. The proper peptide chain elongation was ensured with Ninhydrin test after every coupling step and test cleavage after every third amino acid. After building 10AA amino acid chain, the peptide was cleaved from the solid support or resin. A treatment with 95\% TFA, 5\% tri-isopropylsilane in water, for $2 \mathrm{~h}$ at room temperature with continuous shaking of the vessel was used to simultaneously de-protect the side chains and cleave the crude peptide from the resin. On a semi-preparative RP-HPLC column using gradient elution, $22 \mathrm{mg}$ of the crude 10AA analogue was purified. A gradient method with $10-35 \%$ acetonitrile/water in $60 \mathrm{~min}$ with a flow rate of $1.3 \mathrm{~mL} /$ min was used on the RP-HPLC for the purification of crude synthetic peptide 10 AA.

Peaks eluted at 10.9-11.2, 13.4-14.5, 17-18, 26-27, 27-28, and 33-34 min were collected. Mass spec, through MALDI-TOF with $\alpha$-cyano-4-hydroxycinnamic acid (HCCA) as a matrix, for all of the elutions was taken and elution at peak 13.4-14.5 had the correct mass. Calculated mass for 10AA was 1283 and the mass found was $[\mathrm{M}+\mathrm{H}]^{+}$1282.6. (Additional file 7).

20AA analogue was synthesized in a manner similar to 10AA analogue. Beyond the addition of tenth amino acid, ninhydrin test and test cleavage were performed after every third coupling. Double coupling was performed for the last four amino acids, because of the positive ninhydrin test after single coupling. The purification scheme used for 20AA analogue was the same as the 10AA analogue. Peaks eluted at 13-14.5, 23-25, 29-30, 35-36.5, and 51.5-53 min were collected. Similarly, the MALDITOF mass spectrum for all of the elutions was taken and the correct mass was found in elution at peak 35-36.5 (Additional file 3). Calculated mass for 20AA was 2384 and the mass found was $[\mathrm{M}+\mathrm{H}]^{+} 2383.3$ (Additional file 3). However, complete resolution between 19AA analogue and 20AA analogue could not be achieved. Several other HPLC gradient were tried to achieve resolution of 20AA analogue from other truncated peptides but best results were achieved with $10-35 \%$ acetonitrile/water in $60 \mathrm{~min}$ with a flow rate of $1.3 \mathrm{~mL} / \mathrm{min}$ scheme. Nonetheless, the major component from the eluate was 20AA analogue and 19AA analogue was only a small fraction. Overall 24-28 mg of purified peptide was obtained.

The synthesis of 30AA, linear with all cysteines mutated with valine, was attempted. However, the chain could be elongated only up to 28 AA analogue as identified by mass spec of crude peptide showing a mass of 3386.4 $[\mathrm{M}+\mathrm{H}]^{+}$(Calculated 3387) (Additional file 4). The coupling of arginine to the 28th amino acid valine

\begin{tabular}{lrr}
\hline \multicolumn{1}{c}{ Peptide } & \multicolumn{2}{c}{ Sequence } \\
\hline HBD3 & GIINTLQKYYCRVRGGRCAVLSCLPKEEQIGKCSTRGRKCCRRKK \\
28AA-HBD3 & \multicolumn{2}{c}{ VAVLSVLPKEEQIGKVSTRGRKVVRRKK } \\
20AA-HBD3 & KEEQIGKVSTRGRKVVRKK \\
10AA-HBD3 & \multicolumn{2}{c}{ RGRKVVRRKK } \\
MCCJ25 & GGAGHVPEYFVGIGTPISFYG \\
\hline
\end{tabular}

Figure 1 Amino acid sequences of HBD3, and the three HBD3 fragments. Substitution of cysteine residues with valine in the fragments is shown in red. 
could not be achieved even with three consecutive couplings. Since the manual synthesis of such a long amino acid chain is usually fraught with many pitfalls, the elongation of a 28 amino acid chain was a satisfactory result, because the appropriate balance of positive charge and hydrophobicity was attained.

\section{Microbicidal effect of peptides}

Peptides HBD3, its analogues and Mccj25 were assessed for Minimum bactericidal concentration (MBC). MBC is described as the lowest concentration of each drug that resulted in a $99.9 \%$ reduction in CFU of the initial inoculum. All the peptides have shown intermediate to potent killing activity towards $M$. haemolytica (Figures 2,3). The final inoculum size should be $5 \times 10^{5} \mathrm{cfu} / \mathrm{mL}$, but varied between $1 \times 10^{5}$ and $1 \times 10^{6} \mathrm{cfu} / \mathrm{mL}$ and is acceptable as per M7-A7 guidelines. However, some published studies have taken final inoculum in the range of $10^{4}-10^{5} \mathrm{cfu} / \mathrm{mL}$ [28].

The comparison of antibacterial activity at different concentrations of HBD3 revealed that HBD3 was equally active at $100.0 \mu \mathrm{g} / \mathrm{mL}$ and $50.0 \mu \mathrm{g} / \mathrm{mL}$. However, the concentrations $50 \mu \mathrm{g} / \mathrm{mL}$ and $25.0 \mu \mathrm{g} / \mathrm{mL}, 25.0 \mu \mathrm{g} / \mathrm{mL}$ and

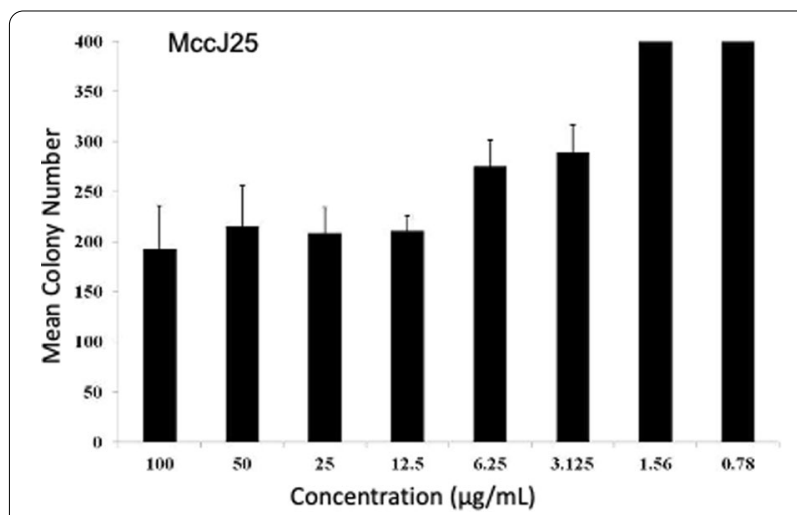

Figure 3 Comparisons between microbicidal effects of eight different concentrations of MccJ25. Comparisons were performed using contrasts for example $100.0 \mu \mathrm{g} / \mathrm{mL}$ was compared to $50.0 \mu \mathrm{g} /$ $\mathrm{mL}, 25.0 \mu \mathrm{g} / \mathrm{mL}$ compared to $12.5 \mu \mathrm{g} / \mathrm{mL}$ employing non-parametric statistics (ranked data). Statistical significance between two concentrations is indicated by ${ }^{*} P<0.05$ and ${ }^{* *}<0.01$. The data are represented as Mean \pm SEM.

$12.5 \mu \mathrm{g} / \mathrm{mL}, 12.5 \mu \mathrm{g} / \mathrm{mL}$ and $6.3 \mu \mathrm{g} / \mathrm{mL}$, and $6.3 \mu \mathrm{g} / \mathrm{mL}$ and $3.1 \mu \mathrm{g} / \mathrm{mL}$ were statistically different. The concentrations $3.1 \mu \mathrm{g} / \mathrm{mL}$ and $0.8 \mu \mathrm{g} / \mathrm{mL}$ were not active and there
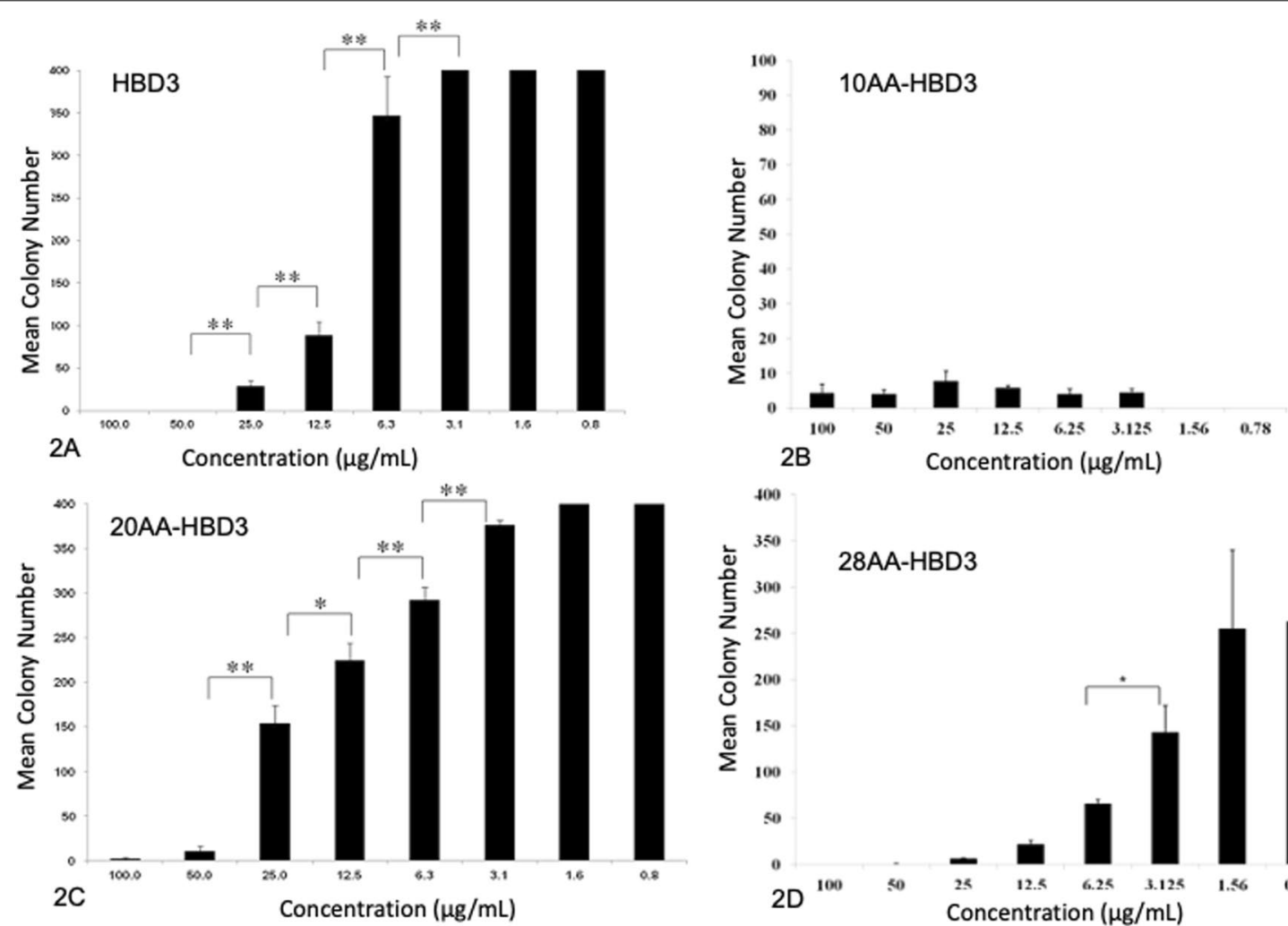

400

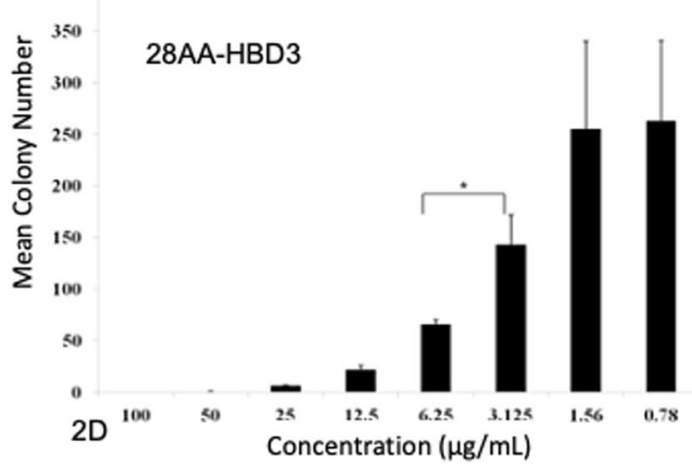

Figure 2 Comparisons between microbicidal effects of eight different concentrations of HBD3 and HBD analogues. Comparisons were performed using contrasts for example $100.0 \mu \mathrm{g} / \mathrm{mL}$ was compared to $50.0 \mu \mathrm{g} / \mathrm{mL}, 25.0 \mu \mathrm{g} / \mathrm{mL}$ compared to $12.5 \mu \mathrm{g} / \mathrm{mL}$ employing non-parametric statistics (ranked data). Statistical significance between two concentrations is indicated by $* P<0.05$ and ${ }^{* *}<0.01$. The data are represented as Mean \pm SEM. 
was no statistical difference between them (Additional file 7 and Figure 2A).

The activity of 10AA at all the concentrations was similar without any statistical difference. It is worth noting that this is observed only with 10AA analogue which is very likely due to a smaller inoculum size $\left(10^{4} \mathrm{cfu} / \mathrm{mL}\right)$ used (Additional file 8 and Figure 2B). Similar to HBD3, 20AA analogue was equally active at both $50.0 \mu \mathrm{g} / \mathrm{mL}$ and $100.0 \mu \mathrm{g} / \mathrm{mL}$. However, the concentrations $50.0 \mu \mathrm{g} /$ $\mathrm{mL}$ and $25.0 \mu \mathrm{g} / \mathrm{mL}, 25.0 \mu \mathrm{g} / \mathrm{mL}$ and $12.5 \mu \mathrm{g} / \mathrm{mL}$, $12.5 \mu \mathrm{g} / \mathrm{mL}$ and $6.3 \mu \mathrm{g} / \mathrm{mL}$, and $6.3 \mu \mathrm{g} / \mathrm{mL}$ and $3.1 \mu \mathrm{g} / \mathrm{mL}$ were statistically different from each other. Again, concentrations $3.1 \mu \mathrm{g} / \mathrm{mL}$ and $0.8 \mu \mathrm{g} / \mathrm{mL}$ were not active and there was no statistical difference among them (Additional file 9 and Figure 2C).

The antibacterial effect of 28AA analogue's concentrations $100.0 \mu \mathrm{g} / \mathrm{mL}$ to $6.3 \mu \mathrm{g} / \mathrm{mL}$ was statistically similar as was the antibacterial effect for the concentrations 3.1$0.8 \mu \mathrm{g} / \mathrm{mL}$. The only difference was observed between 3.1 and $6.3 \mu \mathrm{g} / \mathrm{mL}$ (Additional file 10 and Figure 2D and Additional file 3). Additional file 3 shows a clear dose response when $M$. haemolytica was treated with crude 28AA analogue. The number of colony forming units progressively increased with decreasing peptide concentration. The $\mathrm{MBC}$ and $\mathrm{LD}_{50}$ of all the peptides have been compared (Table 1). While HBD3 and HBD3 20AA analogues have equal $\mathrm{MBC}$ values of $50 \mu \mathrm{g} / \mathrm{mL}, \mathrm{MBC}$ value for HBD3 28AA analogue was the lowest at $12.5 \mu \mathrm{g} / \mathrm{mL}$, and MccJ25 had highest MBC value of $100 \mu \mathrm{g} / \mathrm{mL}$ (Additional file 10$)$. Nearly comparable $\mathrm{LD}_{50}$ values do not effectively discriminate different peptides. However, the value of $\mathrm{LD}_{50}$ is apparent in the fact that it shows Mcc)25 kills half of the bacterial population at $6.3 \mu \mathrm{g} / \mathrm{mL}$.

MccJ25 exhibited microbicidal effect; however, the reduction in colony count was much less in comparison to other peptides Different concentrations of MccJ25 were compared for antibacterial activity against $M$. haemolytica but no statistically significant difference was observed (Additional file 11 and Figure 3).

Table 1 Comparisons of $M B C$ and $L D_{50}$ of the peptides

\begin{tabular}{lcl}
\hline Peptide & MBC $(\boldsymbol{\mu g} / \mathbf{m L})$ & $\mathbf{L D}_{\mathbf{5 0}}(\boldsymbol{\mu g} / \mathbf{m L})$ \\
\hline HBD3 10AA analogue & 6.3 & $\geq 3.1$ \\
HBD3 20AA analogue & 50.0 & 3.1 \\
HBD3 28AA analogue & 12.5 & 3.1 \\
HBD3 & 50.0 & 6.3 \\
MccJ25 & $>100.0$ & 6.3 \\
\hline
\end{tabular}

MBC (Minimum Bactericidal Concentration) is the concentration of antibiotic at which $99.9 \%$ of the CFU in the final inoculum are killed and $\mathrm{LD}_{50}$ is the lethal dose for $\geq 50 \%$ of bacteria.

\section{Chemotaxis assay}

HBD3 is chemotactic for human neutrophils [29]. The chemotaxis of bovine neutrophils in response to HBD3, HBD3 20AA analogue, and HBD3 28AA analogue at $50.0 \mu \mathrm{g} / \mathrm{mL}$ was studied. Neutrophil migration in response to $\mathrm{HBD} 3$ and 20AA analogue was found to be statistically significant when compared with PBS (Negative control), but the difference between PBS and 28AA was not significant (Figure 4). The result shows that HBD3 and HBD3 20AA analogue were chemotactic for bovine neutrophils at $50.0 \mu \mathrm{g} / \mathrm{mL}$ where as $28 \mathrm{AA}$ analogue was not.

\section{Migration inhibition assay}

Bovine neutrophils were treated with $50.0 \mu \mathrm{g} / \mathrm{mL}$ of HBD3, HBD3 20AA analogue, and HBD3 28AA analogue and the effect of peptides on neutrophil migration towards fMLP was studied. Neutrophil migration towards fMLP when neutrophils were incubated with HBD3, HBD3 20AA analogue, and HBD3 28AA analogues was statistically different from the PBS, which shows that none of the peptides inhibited migration of neutrophils towards fMLP (Figure 5).

\section{Discussion}

To our knowledge, this is the first study to show that based on $\mathrm{MBC}$ and $\mathrm{LD}_{50}$ data HBD3 and its analogues and MccJ25 peptides kill $M$. haemolytica in vitro. In addition, the peptides are chemotactic for the bovine neutrophils. These data are important considering the economic impact of morbidity and mortality associated with BRD

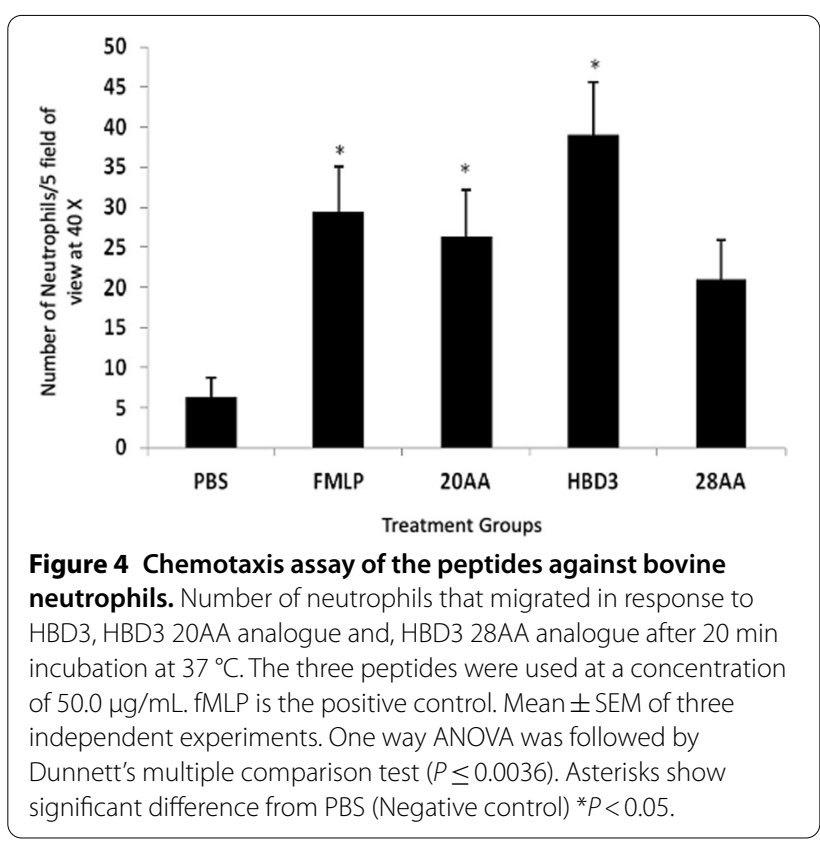


caused by $M$. hemotlyica. The development and use of antimicrobial peptides may also provide us with tools to reduce the use of antibiotics and thus reduce the threat of anti-microbial resistance and their residues in meat.

HBD3 and MccJ25 were selected as potential candidates. Wild-type HBD3 with purity $\geq 95 \%$ was commercially obtained, whereas MccJ25 was expressed in $E$. coli followed by purification and characterization. The data contained in this study show synthesis and characterization of three analogues of HBD3. We successfully synthesized HBD3 analogues (Figure 1) namely 10AA, 20AA but couldn't synthesize 30AA using Fmoc-SPPS. During SPPS, the -amino acid chain could be elongated up to only 28AA as confirmed by MALDI-TOF even after repeated coupling. Mass spectrometry of 28AA crude peptide shows other peaks along with 28AA analogue peak suggesting impurities in the crude peptide. The crude peptides (MccJ25, 10AA and 20AA analogue) were purified by RP-HPLC and then by MALDI-TOF mass spectrometry to confirm mass of the crude and pure peptides.

In vitro susceptibility tests for cationic peptides are challenging to perform because polycationic peptides tend to precipitate and bind to the anionic surface of bacterial cells and plastic surface. There are data on the comparison of two methods for evaluating the in vitro antimicrobial activities of cationic AMP's [30]. The comparative data showed that NCCLS protocol gave MICs



Figure 5 Effect of peptides on neutrophil migration towards

fMLP. Number of neutrophils that migrated towards fMLP (114 nM) after 20 min incubation at $37^{\circ} \mathrm{C}$. Neutrophils were treated with $50.0 \mu \mathrm{g} / \mathrm{mL}$ HBD3, HBD3 20AA analogue and, HBD3 28AA analogue. $\mathrm{pn} / \mathrm{f}$ stands for peptide and neutrophils together in the upper well and fmlp in the bottom during 20 min incubation. FMLP is the positive control. Mean \pm SEM of three independent experiments. One way ANOVA was followed by Dunnett's multiple comparison test $(P \leq 0.0036)$. Asterisks show significant difference from PBS (Negative control) ${ }^{*} P<0.05$. and $\mathrm{MBCs}$ values that were four times higher than the method proposed by Hancock [30]. We used the 96-well plates for antimicrobial evaluation to reduce the possibility of false higher MBCs and MICs as apparent in the results of Giacometti and the results of our preliminary MIC experiment (data not shown). However, we used the NCCLS definition of MBC which is the lowest concentration of each drug that resulted in a $99.9 \%$ reduction in CFU of the initial inoculum whereas the Hancock method defines the MBC as the lowest concentration of each drug that prevented any residual colony formation. In addition to the MBC, we also carried out the MIC assays. This classification of peptide potency however is arbitrary, "a strain was defined as sensitive to the peptide if $\mathrm{MBC}$ levels were $<10 \mu \mathrm{g} / \mathrm{mL}$, as intermediately sensitive if $\mathrm{MBC}$ levels were $10-100 \mu \mathrm{g} / \mathrm{mL}$, or as resistant at MBC levels of $>100 \mu \mathrm{g} / \mathrm{mL}$ " [28].

In our study, HBD3 was highly effective in killing $M$. haemolytica with $\mathrm{MBC}$ value of $50 \mu \mathrm{g} / \mathrm{mL}$. The testing of the bactericidal activity of the HBD3 against 28 species and 55 strains of Gram-positive cocci and Gram-negative fermentative and non-fermentative rods showed it be intermediately or highly effective [28]. However, MBC value in our study is higher when compared to the data from Sahly et al. in which only three strains out of 55 tested showed intermediate susceptibility (MBC value of $50.0 \mu \mathrm{g} / \mathrm{mL}$ ), whereas rest of the strains were highly sensitive to HBD3 with MBC's ranging from 0.1 to $6.3 \mu \mathrm{g} /$ $\mathrm{mL}$ [28]. The reason for lower MBC's in their study could be attributed to use of a lower final bacterial inoculum of $10^{4}$ to $10^{5} / \mathrm{mL}$ [28] compared $10^{5}$ to $10^{6} / \mathrm{mL}$ used in our study. This phenomenon of lower MBC corresponding with low final inoculum size was also observed in our data from 10AA analogue. We tested various concentrations of this analogue with final inoculum size of $10^{4}$ cells $/ \mathrm{mL}$ of $M$. haemolytica and this gave us MBC of $6.3 \mu \mathrm{g} / \mathrm{mL}$.

HBD3 analogues showed intermediate activity against $M$. hemolytica. 20AA analogue was active against $M$. haemolytica in the same concentration as the wild type HBD3, after averaging results from three different experiments, in duplicates, they showed equivalent $\mathrm{MBC}$ values. $20 \mathrm{AA}$ analogue's potent activity is likely attributable to its high positive charge (+9). HBD has a higher positive charge of +11 but showed anti-microbial activity similar to that of 20AA analogue. Therefore, it will be interesting to replace a couple of positively charged basic polar amino acids such as arginine or lysine with valine, a neutral nonpolar amino acid, to the analogue more hydrophobic and increasingly selective for bacterial membranes. This argument is further supported by the fact that 10 AA analogue with +7 charge displayed excellent activity against $M$. haemolytica with $6.3 \mu \mathrm{g} / \mathrm{mL} \mathrm{MBC}$ 
when used with a small inoculum. The testing of this analogue with a higher bacterial inoculum, similar to other peptides, would have further bolstered our results. Nevertheless, $\mathrm{MBC}$ of 10AA analogue was lower than both HBD3 and 20AA analogue and therefore we may be able extrapolate this result for higher inoculum size.

Zhou et al. made eight C-terminal 10AA analogues of HBD3 replacing cysteines with either Valine, Tryptophan or Tyrosine. Out of these, Valine was easier to build via SPPS synthesis and was found to be most active and it also didn't affect antimicrobial activity against bacteria such as Pseudomonas aeruginosa [31]. Because cysteine and methionine are prone to oxidation, they are often replaced by hydrophobic residues such as valine [32]. They also made a dimer of Valine 10AA analogue, which turned out to be the most potent analogue. Instead of making a dimer of 10AA analogue, we chose to elongate the peptide chain up to 20 and 28 AA with mutation of all Cysteines with Valines. Both 20AA and 28AA analogues were active with 28AA peptide showing better activity than wild-type HBD3 [31]. These researchers further tested their peptides against Pseudomonas aeruginosa, a Gram -ve bacteria, in the same concentration range as ours. Comparing their study with ours, we found that the 10AA analogue had similar MBC values $(50.0 \mu \mathrm{g} / \mathrm{mL})$ for both Pseudomonas aeruginosa and M. haemolytica. However, their dimer was more potent than our 20AA analogue. The in vitro data also shows that removal of disulfide bonds does not affect the antimicrobial potency of the peptides as shown previously [29]. However, in vivo studies are required to further establish this observation.

Studies have shown that some C-terminal (R36-K45) analogues of HBD-3 can non-covalently dimerize to acquire a defined structure in conditions mimicking biological systems or on the lipid bilayer [31, 33]. Elucidating the underlying physico-chemical properties was beyond the scope of this study. However, we can speculate about the 3D structure of 20AA analogue based on the nearly comparable $\mathrm{MBC}$ results of 20AA analogue with wtHBD3, and findings of the previous studies performed with NMR, fluorescence correlation spectroscopy and molecular dynamics simulation techniques [33]. It is possible that the 20AA analogue, dimerized both in aqueous solution and on the membrane surfaces, which tend to localize the positive charge density which may account for its bactericidal efficacy. Alternatively, the 20AA analogue would just remain as a linear monomer and its potent activity results from increased flexibility due to a loss of secondary structure. It also is possible that the activity of 20AA analogue could be due to truncated peptide (19AA) that coeluted during purification of the peptide and was used.
Mcc)25 kills bacteria by inhibiting the RNA Polymerase (RNAP) but this microcin peptide has to enter the bacterial cell to accomplish this action. The MccJ5 sensitive strains have the transporter proteins such as outer-membrane protein FhuA and the inner membrane protein SbmA to facilitate the transport of the antimicrobial peptides into the cells $[34,35]$. There are some data on the characterization of outer membrane proteins of $M$. haemolytica $[36,37]$ but we don't know whether specific membrane proteins exist to facilitate transport of MccJ25. Furthermore, Mcc)25 is not effective against many bacteria of the family Enterobacteriaceae that are not related to the MccJ25 producing members [38]. It could be argued that MccJ25 shows a narrow action spectrum activity in vitro but could be active in vivo against resistant species [38, 39]. It has been shown that resistant bacteria become susceptible to antibiotics upon their entry into the low $\mathrm{pH}$ environment in the phagolysosomes of macrophages likely due to the nonspecific MccJ25 uptake into the bacterial cell through altered bacterial membrane permeability. Also, MccJ25 has been shown to cause disruption of the membrane potential [39] and hence it can be speculated that inside a macrophage $M$. haemolytica could become sensitive to Mcc)25.

None of the five peptides tested by us inhibited visible growth of the M. haemolytica when compared with the positive control. The bactericidal nature of the cationic peptides could be the possible explanation of these results. Ampicillin at a concentration of $24 \mu \mathrm{g} / \mathrm{mL}$ served as negative control in our experiments and there was no growth in the negative wells. Since there were $10000-25000$ bacteria/well and even if $0.1 \%$ of them survived and the peptide got consumed or deactivated over next few hours and media was still available for their growth. It is very likely that bacteria resumed growth to give false negatives. To ascertain the real cause, we need to do additional timekill studies as well as testing against other serotypes of $M$. haemolytica.

Anti-microbial peptides kill microbes and have immunomodulatory functions such as modulating recruitment of neutrophils [40]. Defensins such as HBD2 but not HBD1 have been shown to be chemotactic for human neutrophils pre-treated with TNF- $\alpha$ but not normal in vitro [35]. Our data show HBD3 and its 20AA analogue to be chemotactic to control untreated bovine neutrophils. The difference in results from our experiments and those obtained previously may be reflective of species differences. Furthermore, we used the peptides at $50.0 \mu \mathrm{g} /$ $\mathrm{mL}$ and compared to concentrations of $0-10 \mu \mathrm{g} / \mathrm{mL}$ in previous studies [41]. To elucidate the chemotactic behavior of 20AA analogue it must be tested against a wide concentration range and also for neutrophils from other species. It was earlier reported that cysteine mutated 
analogues of HBD3 might lose their chemotactic activity. It might be possible that bovine neutrophils are generally responsive to the Cysteine mutated HBD3 analogues. The data by Taylor et al. demonstrated the indispensability of three cysteine disulfide bridges for chemotactic activity [42]. They showed that HBD3 analogues lacking disulfide bridges retained chemoattractant capability. HBD3 analogue which had cysteines replaced with alanines was devoid of any chemotactic activity. However, the chemotactic activity was not lost when the fifth cysteine was retained and other five were replaced. These anomalous results could be due to variation in environmental conditions or different cell species used [42]. The chemotaxis in 28AA analogue well and PBS well was statistically not different. This anomaly can be accounted for if we take into consideration that 28AA was in crude form and had contained a few truncated peptides. Lastly, the treatment of neutrophils with any of peptides did not affect their migration towards fMLP. Nevertheless, there is a need for additional experiments to understand the relationship between structure and function of the HBD3 and its linear analogues with their chemotactic property.

Taken together, we report the engineering and synthesis of HBD analogues and MccJ25 and report their efficacy in killing of $M$. haemolytica and chemotactic properties against bovine neutrophils. Further experiments are needed to evaluate the activity against other serotypes of M. haemolytica, in vivo studies and cell cytotoxicity assays.

\section{Supplementary Information}

The online version contains supplementary material available at https://doi. org/10.1186/s13567-021-00956-4

\begin{abstract}
Additional file 1. Microcin J25 characterization. A) HPLC chromatogram of crude Microcin J25 (MccJ25) showing elution of MccJ25 at 20 min following acetonitrile/water gradient on a reversed-phase column. $\mathrm{mAU}$ is a symbol for the milli-absorbance unit. B) MALDI-TOF of pure MccJ25, purified by reversed-phase HPLC, showing $[\mathrm{M}+\mathrm{H}]+$ + peak (observed 2107.7 and calculated. 2107). Intensity is relative abundance or signal intensity of the ions and $\mathrm{m} / \mathrm{z}$ is mass to charge ratio.
\end{abstract}

Additional file 2. HBD3 10AA analogue characterization. A) HPLC chromatogram of crude 10AA analogue showing elution of at $13.1 \mathrm{~min}$ following acetonitrile/water gradient on a reversed-phase column. $\mathrm{mAU}$ is a symbol for the milli-absorbance unit. Panel B shows MALDI-TOF of pure 10AA analogue, purified by reversed-phase HPLC, showing $[\mathrm{M}+\mathrm{H}]^{+}$peak (found 1282.6, calculated. 1283) (B). Intensity is relative abundance or signal intensity of the ions and $\mathrm{m} / \mathrm{z}$ is mass to charge ratio.

Additional file 3. HBD3 20AA analogue characterization. (A) HPLC chromatogram of crude 20AA analogue showing elution at $35 \mathrm{~min}$ following acetonitrile/water gradient on a reversed-phase column. mAU is a symbol for the milli-absorbance unit. (B) MALDI-TOF of pure 20AA analogue, purified by reversed-phase HPLC, showing $[\mathrm{M}+\mathrm{H}]^{+}$peak (found 2383.1, calculated. 2384). $\mathrm{m} / \mathrm{z}$ is mass to charge ratio and Intensity is relative abundance or signal intensity of the ions.

Additional file 4. HBD3 28AA analogue characterization. Panels A shows MALDI-TOF of crude 28AA analogue, showing $[\mathrm{M}+\mathrm{H}]^{+}$peak (found 3386.4 , calculated. 3387 ). $\mathrm{m} / \mathrm{z}$ is mass to charge ratio and Intensity is relative abundance or signal intensity of the ions.
Additional file 5. Characterization of microbicidal activity of HBD3 28 AA analogue. Colony forming units of $M$. haemolytica; that survived after incubation with $28 \mathrm{AA}$ analogue at concentration $50.0 \mu \mathrm{g} / \mathrm{mL}$ (A), $25.0 \mu \mathrm{g} /$ $\mathrm{mL}$ (B), $12.5 \mu \mathrm{g} / \mathrm{mL}$ (C), $6.25 \mu \mathrm{g} / \mathrm{mL}$ (D), Negative control plate (E) and positive control plate $(\mathrm{F})$.

Additional file 6. Gradient elution scheme for 10AA and 20AA HBD3 analogues.

Additional file 7. Number of colony forming units after treatment with HBD3.

Additional file 8. Number of colony forming units after treatment with HBD3 10 AA analogue.

Additional file 9. Number of colony forming units after treatment with HBD3 20 AA analogue.

Additional file 10. Number of colony forming units after treatment with HBD3 28 AA analogue.

Additional file 11. Number of colony forming units after treatment with Mccj25.

\section{Acknowledgements}

We acknowledge the support of veterinary microbiology diagnostic laboratory at Western College of Veterinary Medicine, University of Saskatchewan.

\section{Authors' contributions}

BS and KK conceptualized the study. HD performed all the experiments and data analysis. Manuscript was written by HD and final review was done by both BS and KK. All authors read and approved the final manuscript.

\section{Funding}

This research was supported by research Grant from Alberta and Livestock Meat Agency to Dr Baljit Singh and Dr Kamaljit Kaur and a Discovery Grant from Natural Sciences and Engineering Research Council of Canada to Dr Baljit Singh.

\section{Availability of data and materials}

The protocols and the data obtained from the experiments reported in the manuscript are included in the Additional tables and figures.

\section{Declarations}

Ethics approval and consent to participate

The study was approved by the University of Saskatchewan's Committee on Animal Care

\section{Consent for publication}

All the authors have read the manuscript and approved it. The manuscript was part of the MSc thesis by Mr. Harpreet Dhingra, the first author of the study.

\section{Competing interests}

The authors declare that they have no competing interests.

\section{Author details}

${ }^{1}$ Department of Veterinary Biomedical Science, Western College of Veterinary Medicine, University of Saskatchewan, Saskatoon, SK S7N 5B4, Canada. ${ }^{2}$ Chapman University School of Pharmacy (CUSP), Harry and Diane Rinker Health Science Campus, Chapman University, Irvine, CA 92618-1908, USA.

Received: 26 December 2020 Accepted: 3 May 2021

Published online: 10 June 2021

References

1. Taylor JD, Fulton RW, Lehenbauer TW, Step DL, Confer AW (2010) The epidemiology of bovine respiratory disease: what is the evidence for preventive measures? Can Vet J 51:1351-1359 
2. Loneragan GH, Dargatz DA, Morley PS, Smith MA (2001) Trends in mortality ratios among cattle in US feedlots. J Am Vet Med Assoc 219:1122-1127

3. Rice JA, Carrasco-Medina L, Hodgins DC, Shewen PE (2007) Mannheimia haemolytica and bovine respiratory disease. Anim Health Res Rev 8:117-128. https://doi.org/10.1017/S1466252307001375

4. Whiteley LO, Maheswaran SK, Weiss DJ, Ames TR, Kannan MS (1992) Pasteurella haemolytica $\mathrm{A} 1$ and bovine respiratory disease: pathogenesis. J Vet Intern Med 6:11-22

5. Czuprynski CJ, Leite F, Sylte M, Kuckleburg C, Schultz R, Inzana T, BehlingKelly E, Corbeil L (2004) Complexities of the pathogenesis of Mannheimia haemolytica and Haemophilus somnus infections: challenges and potential opportunities for prevention? Anim Health Res Rev 5:277-282

6. Singh K, Ritchey JW, Confer AW (2011) Mannheimia haemolytica: bacterial-host interactions in bovine pneumonia. Vet Pathol 48:338-348. https://doi.org/10.1177/0300985810377182

7. Blakebrough-Hall C, McMeniman JP, Gonzalez LA (2020) An evaluation of the economic effects of bovine respiratory disease on animal performance, carcass traits, and economic outcomes in feedlot cattle defined using four BRD diagnosis methods. J Anim Sci 98:skaa005. https://doi. org/10.1093/jas/skaa005

8. Klima CL, Holman DB, Cook SR, Conrad CC, Ralston BJ, Allan N, Anholt RM, Niu YD, Stanford K, Hannon SJ, Booker CW, McAllister TA (2020) Multidrug resistance in Pasteurellaceae associated with bovine respiratory disease mortalities in North America from 2011 to 2016. Front Microbiol 11:606438. https://doi.org/10.3389/fmicb.2020.606438

9. Amat S, Timsit E, Baines D, Yanke J, Alexander TW (2019) Development of bacterial therapeutics against the bovine respiratory pathogen Mannheimia haemolytica. Appl Environ Microbiol 85:e01359-e1419. https:// doi.org/10.1128/AEM.01359-19

10. Sit CS, Vederas JC (2008) Approaches to the discovery of new antibacterial agents based on bacteriocins. Biochem Cell Biol 86:116-123. https:// doi.org/10.1139/007-153

11. Blond A, Peduzzi J, Goulard C, Chiuchiolo MJ, Barthelemy M, Prigent Y, Salomon RA, Farias RN, Moreno F, Rebuffat S (1999) The cyclic structure of microcin J25, a 21-residue peptide antibiotic from Escherichia coli. Eur J Biochem 259:747-755

12. Laube DM, Yim S, Ryan LK, Kisich KO, Diamond G (2006) Antimicrobial peptides in the airway. Curr Top Microbiol Immunol 306:153-182

13. Vulikh K, Bassel LL, Sergejewich L, Kaufman El, Hewson J, Maclnnes J, Tabatabaei S, Caswell JL (2019) Effect of tracheal antimicrobial peptide on the development of Mannheimia haemolytica pneumonia in cattle. PLoS One 14:e0225533. https://doi.org/10.1371/journal.pone.0225533

14. Taha-Abdelaziz K, Perez-Casal J, Schott C, Hsiao J, Attah-Poku S, Slavic D, Caswell JL (2013) Bactericidal activity of tracheal antimicrobial peptide against respiratory pathogens of cattle. Vet Immunol Immunopathol 152:289-294. https://doi.org/10.1016/j.vetimm.2012.12.016

15. Blond A, Cheminant M, Segalas-Milazzo I, Peduzzi J, Barthelemy M, Goulard C, Salomon R, Moreno F, Farias R, Rebuffat S (2001) Solution structure of microcin $J 25$, the single macrocyclic antimicrobial peptide from Escherichia coli. Eur J Biochem 268:2124-2133

16. Asensio C, Perez-Diaz JC (1976) A new family of low molecular weight antibiotics from enterobacteria. Biochem Biophys Res Commun 69:7-14

17. Baquero F, Moreno F (1984) The microcins. FEMS Microbiol Lett 23:117124. https://doi.org/10.1111/j.1574-6968.1984.tb01046.x

18. Ding X, Yu H, Qiao S (2020) Lasso peptide microcin J25 effectively enhances gut barrier function and modulates inflammatory response in an enterotoxigenic Escherichia coli-challenged mouse model. Int J Mol Sci 21:6500. https://doi.org/10.3390/ijms21186500

19. Yu H, Wang Y, Zeng $X$, Cai S, Wang G, Liu L, Huang S, Li N, Liu H, Ding $X$, Song Q, Qiao S (2020) Therapeutic administration of the recombinant antimicrobial peptide microcin J25 effectively enhances host defenses against gut inflammation and epithelial barrier injury induced by enterotoxigenic Escherichia coli infection. Faseb J 34:1018-1037. https://doi.org/ 10.1096/fi.201901717R

20. Galvan AE, Chalon MC, Rios Colombo NS, Schurig-Briccio LA, Sosa-Padilla B, Gennis RB, Bellomio A (2019) Microcin J25 inhibits ubiquinol oxidase activity of purified cytochrome bd-I from Escherichia coli. Biochimie 160:141-147. https://doi.org/10.1016/j.biochi.2019.02.007
21. Wang G, Song $Q$, Huang $S$, Wang $Y$, Cai S, Yu H, Ding X, Zeng X, Zhang J (2020) Effect of antimicrobial peptide microcin $J 25$ on growth performance, immune regulation, and intestinal microbiota in broiler chickens challenged with Escherichia coli and Salmonella. Animals 10:345. https:// doi.org/10.3390/ani10020345

22. Soudy R, Gill A, Sprules T, Lavasanifar A, Kaur K (2011) Proteolytically stable cancer targeting peptides with high affinity for breast cancer cells. J Med Chem 54:7523-7534. https://doi.org/10.1021/jm200750x

23. Gazit E, Bach D, Kerr ID, Sansom MS, Chejanovsky N, Shai Y (1994) The a-5 segment of Bacillus thuringiensis delta-endotoxin: in vitro activity, ion channel formation and molecular modelling. Biochem J 304:895-902

24. Rapaport D, Peled R, Nir S, Shai Y (1996) Reversible surface aggregation in pore formation by pardaxin. Biophys J 70:2502-2512. https://doi.org/10. 1016/S0006-3495(96)79822-3

25. Pouny Y, Shai Y (1992) Interaction of D-amino acid incorporated analogues of pardaxin with membranes. Biochemistry 31:9482-9490

26. Le MH, Suri SS, Rakotondradany F, Fenniri H, Singh B (2010) Rosette nanotubes inhibit bovine neutrophil chemotaxis. Vet Res 41:75. https:// doi.org/10.1051/vetres/2010047

27. Soudy R, Wang L, Kaur K (2012) Synthetic peptides derived from the sequence of a lasso peptide microcin J25 show antibacterial activity. Bioorg Med Chem 20:1794-1800. https://doi.org/10.1016/j.bmc.2011.12. 061

28. Sahly H, Schubert S, Harder J, Rautenberg P, Ullmann U, Schroder J, Podschun R (2003) Burkholderia is highly resistant to human $\beta$-defensin 3. Antimicrob Agents Chemother 47:1739-1741

29. Wu Z, Hoover DM, Yang D, Boulegue C, Santamaria F, Oppenheim JJ, Lubkowski J, Lu W (2003) Engineering disulfide bridges to dissect antimicrobial and chemotactic activities of human $\beta$-defensin 3. Proc Natl Acad Sci USA 100:8880-8885. https://doi.org/10.1073/pnas.1533186100

30. Giacometti A, Cirioni O, Barchiesi F, Del Prete MS, Fortuna M, Caselli F, Scalise G (2000) In vitro susceptibility tests for cationic peptides: comparison of broth microdilution methods for bacteria that grow aerobically. Antimicrob Agents Chemother 44:1694-1696

31. Zhou L, Liu SP, Chen LY, Li J, Ong LB, Guo L, Wohland T, Tang CC, Lakshminarayanan R, Mavinahalli J, Verma C, Beuerman RW (2011) The structural parameters for antimicrobial activity, human epithelial cell cytotoxicity and killing mechanism of synthetic monomer and dimer analogues derived from hBD3 C-terminal region. Amino Acids 40:123-133. https:// doi.org/10.1007/s00726-010-0565-8

32. Kaur K, Andrew LC, Wishart DS, Vederas JC (2004) Dynamic relationships among type lla bacteriocins: temperature effects on antimicrobial activity and on structure of the $\mathrm{C}$-terminal amphipathic a helix as a receptorbinding region. Biochemistry 43:9009-9020. https://doi.org/10.1021/ bi036018e

33. Bai Y, Liu S, Jiang P, Zhou L, Li J, Tang C, Verma C, Mu Y, Beuerman RW, Pervushin K (2009) Structure-dependent charge density as a determinant of antimicrobial activity of peptide analogues of defensin. Biochemistry 48:7229-7239. https://doi.org/10.1021/bi900670d

34. Salomon RA, Farias RN (1995) The peptide antibiotic microcin 25 is imported through the TonB pathway and the SbmA protein. J Bacteriol 177:3323-3325

35. Salomon RA, Farias RN (1993) The FhuA protein is involved in microcin 25 uptake. J Bacteriol 175:7741-7742

36. Confer AW, Ayalew S (2018) Mannheimia haemolytica in bovine respiratory disease: immunogens, potential immunogens, and vaccines. Anim Health Res Rev 19:79-99. https://doi.org/10.1017/S1466252318000142

37. Ayalew S, Confer AW, Hartson SD, Shrestha B (2010) Immunoproteomic analyses of outer membrane proteins of Mannheimia haemolytica and identification of potential vaccine candidates. Proteomics 10:2151-2164. https://doi.org/10.1002/pmic.200900557

38. Pomares MF, Corbalan NS, Adler C, de Cristobal R, Farias RN, Delgado MA, Vincent PA (2013) Macrophage environment turns otherwise MccJ25resistant Salmonella into sensitive. BMC Microbiol 13:95. https://doi.org/ 10.1186/1471-2180-13-95

39. Rintoul MR, de Arcuri BF, Salomon RA, Farias RN, Morero RD (2001) The antibacterial action of microcin J25: evidence for disruption of 
cytoplasmic membrane energization in Salmonella newport. FEMS Microbiol Lett 204:265-270. https://doi.org/10.1111/j.1574-6968.2001.tb108 95.x

40. Yang D, Biragyn A, Kwak LW, Oppenheim JJ (2002) Mammalian defensins in immunity: more than just microbicidal. Trends Immunol 23:291-296

41. Niyonsaba F, Ogawa $H$, Nagaoka I (2004) Human $\beta$-defensin-2 functions as a chemotactic agent for tumour necrosis factor-a-treated human neutrophils. Immunology 111:273-281

42. Taylor K, Clarke DJ, McCullough B, Chin W, Seo E, Yang D, Oppenheim J, Uhrin D, Govan JR, Campopiano DJ, MacMillan D, Barran P, Dorin JR (2008)
Analysis and separation of residues important for the chemoattractant and antimicrobial activities of $\beta$-defensin 3. J Biol Chem 283:6631-6639. https://doi.org/10.1074/jbc.M709238200

\section{Publisher's Note}

Springer Nature remains neutral with regard to jurisdictional claims in published maps and institutional affiliations.
Ready to submit your research? Choose BMC and benefit from:

- fast, convenient online submission

- thorough peer review by experienced researchers in your field

- rapid publication on acceptance

- support for research data, including large and complex data types

- gold Open Access which fosters wider collaboration and increased citations

- maximum visibility for your research: over $100 \mathrm{M}$ website views per year

At BMC, research is always in progress.

Learn more biomedcentral.com/submissions 